\title{
A podiatry-led Peripheral Arterial Disease service - observations and early outcomes
}

\author{
Martin Fox, Lisa Smith, Louise Stuart MBE, Helene Gordon, Michelle Proudman \\ From Society of Chiropodists and Podiatrists Annual Conference 2010 \\ Bournemouth, UK. 21-23 October 2010
}

\section{Introduction}

Peripheral Arterial Disease (PAD) is significant issue in the UK. Under diagnosis and management results in avoidable heart attacks, strokes and amputations. Our NHS organisation has commissioned a new Podiatryled, multidisciplinary, community-based, PAD service. It is focussed on stimulating identification, diagnosis and management, as part of an approach to address poor local cardiovascular disease (CVD) outcomes. We will outline the development and description of the service model and present initial outcomes from it. This will complement the key conference theme of peripheral arterial disease, as presented by Prof. Cliff Shearman.

\section{Methods}

We describe how we used best clinical evidence (SIGN, 2006) as a foundation for defining the clinical content and pathways. The service specification outlined key areas for delivery and progress reporting. We will give an overview of our service development plan, which has focussed on developing proactive initiatives and outcomes in these areas, via broad stakeholder engagement.

\section{Results}

Results on referral patterns, subsequent PAD diagnosis \& severity, treatment and patient satisfaction will be presented.

\section{Discussion}

Discussion of the added value of this service within the traditional NHS Podiatry / PAD / CVD service land-

NHS Manchester, Manchester, UK scape will be presented, along with recommendations for further strengthening the service model.

Published: 20 December 2010

doi:10.1186/1757-1146-3-S1-010

Cite this article as: Fox et al:: A podiatry-led Peripheral Arterial Disease service - observations and early outcomes. Journal of Foot and Ankle Research 2010 3(Suppl 1):010.
Submit your next manuscript to BioMed Central and take full advantage of:

- Convenient online submission

- Thorough peer review

- No space constraints or color figure charges

- Immediate publication on acceptance

- Inclusion in PubMed, CAS, Scopus and Google Scholar

- Research which is freely available for redistribution

\section{C) Biomed Central}

(c) 2010 Fox et al; licensee BioMed Central Ltd. This is an open access article distributed under the terms of the Creative Commons Attribution License (http://creativecommons.org/licenses/by/2.0), which permits unrestricted use, distribution, and reproduction in any medium, provided the original work is properly cited. 